OPEN ACCESS

Edited by:

Roger Chammas,

University of São Paulo, Brazil

Reviewed by:

Mauro Sergio Pavao,

Federal University of Rio de Janeiro,

Brazil

Lubor Borsig,

University of Zurich, Switzerland

*Correspondence:

Israel Vlodavsky

Vlodavsk@mail.huji.ac.il

Specialty section:

This article was submitted to

Molecular and Cellular Oncology,

a section of the journal

Frontiers in Oncology

Received: 09 November 2020 Accepted: 09 December 2020

Published: 29 January 2021

Citation:

Gross-Cohen M, Feld S, Arvatz G, Ilan N and Vlodavsky I (2021)

Elucidating the Consequences of

Heparan Sulfate Binding by

Heparanase 2.

Front. Oncol. 10:627463.

doi: 10.3389/fonc.2020.627463

\section{Elucidating the Consequences of Heparan Sulfate Binding by Heparanase 2}

\author{
Miriam Gross-Cohen, Sari Feld, Gil Arvatz, Neta llan and Israel Vlodavsky ${ }^{*}$ \\ Technion Integrated Cancer Center, Rappaport Faculty of Medicine, Technion, Haifa, Israel
}

Unlike the intense research effort devoted to exploring the significance of heparanase in human diseases, very little attention was given to its close homolog, heparanase 2 (Hpa2). The emerging role of $\mathrm{Hpa} 2$ in a rare autosomal recessive congenital disease called urofacial syndrome (UFS), clearly indicates that Hpa2 is not a pseudogene but rather a gene coding for an important protein. Hpa2 lacks the heparan sulfate (HS)-degrading activity typical of heparanase, yet exhibits high affinity to HS, affinity that is 10-fold higher than that of heparanase. The consequences of this high-affinity interaction of $\mathrm{Hpa} 2$ with plasma membrane HSPG has not been explored yet. Here, we used highly purified Hpa2 protein to examine this aspect. We provide evidence that cells adhere to and spread on dishes coated with Hpa2. We also show that cell migration is attenuated markedly by exogenous addition of Hpa2 to primary and transformed cells, a function that agrees with the anti-cancer properties of Hpa2. Interestingly, we found that exogenous addition of Hpa2 also disrupts the morphology of cell colonies, resulting in cell scattering. This implies that under certain conditions and experimental settings, Hpa2 may exhibit protumorigenic properties. We further developed a panel of anti-Hpa2 monoclonal antibodies $(\mathrm{mAb})$ and show that these properties of Hpa2 are prevented by some of the newly-developed mAb, thus providing new molecular tools to better appreciate the significance of Hpa2 in health and disease.

Keywords: heparanase, heparanase 2, heparan sulfate, adhesion, migration, scattering

\section{INTRODUCTION}

Heparanase is a unique enzyme due to its endoglycosidase activity, capable of cleaving heparan sulfate (HS) side chains of heparan sulfate proteoglycans (HSPG). HSPG are highly abundant in the extracellular matrix (ECM) and assist to assemble the major protein constituents of the ECM (i.e., laminin, fibronectin, collagen-IV, etc.) into a three-dimensional, non-soluble, thick matrix that provides structural support and biochemical cues to many cell types. Cleavage of HS by heparanase thus results in remodeling of the ECM. These structural and biochemical alterations are expected to exert a profound impact on cell behavior including, among others, cell differentiation, proliferation, migration, and invasion. The latter is most often associated with increased metastatic capacity of tumor cells and augmented entry of inflammatory cells (i.e., T-cells, macrophages, NK-cells) to sites of inflammation (1-3). Heparanase also cleaves HSPG on the cell surface (i.e., syndecans), affecting 
their ability to function as co-receptors in signaling pathways. In addition, cleavage of the HS side chains of syndecan-1 augments the shedding of this proteoglycan from the surface of myeloma cells, leading to a more aggressive disease $(4,5)$. This, and many other mechanisms utilized by heparanase to promote tumorigenesis (3,5-9), have turned this enzyme into a promising drug target and heparanase inhibitors are currently being evaluated in clinical trials as anti-cancer $(10,11)$ and antiviral (12) drugs.

Heparanase 2 (Hpa2) is a close homolog of heparanase; it shows an overall identity of $40 \%$ and sequence resemblance of $59 \%$ with heparanase, including conservation of residues critical for heparanase enzymatic activity $\left(\mathrm{Glu}_{225}\right.$ and $\left.\mathrm{Glu}_{343}\right)$ (13). Hpa2 nonetheless lacks the HS-degrading activity typical of heparanase (14). Like heparanase, Hpa2 is secreted and interacts with cell membrane syndecans. Unlike heparanase, $\mathrm{Hpa} 2$ is not internalized into endocytic vesicles but rather is retained on the cell membrane for a relatively long period of time (14). The reason for the failure of Hpa2 to get internalized is not known, but may be due to its high affinity to HS, affinity that is 10-fold higher than that of heparanase (14). The consequences of this high-affinity interaction of Hpa2 with plasma membrane HSPG have not been explored yet. Here, we used highly purified $\mathrm{Hpa} 2$ protein to examine this aspect. We provide evidence that cells adhere to and spread on dishes coated with Hpa2. We also show that cell migration is attenuated markedly by exogenous addition of $\mathrm{Hpa} 2$ to primary and transformed cells, a function that agrees with the anti-cancer properties of Hpa2 (14-17). Interestingly, we found that exogenous addition of Hpa2 also disrupts the morphology of cell colonies, resulting in cell scattering. This implies that under certain conditions and experimental settings, Hpa2 may exhibit pro-tumorigenic properties. Importantly, attenuation of cell migration and cell scattering by $\mathrm{Hpa} 2$ appears to be HS-dependent and was attenuated by heparin. We further developed a panel of anti-Hpa2 monoclonal antibodies $(\mathrm{mAb})$ and show that these properties of $\mathrm{Hpa} 2$ are prevented by some of the newly-developed $\mathrm{mAb}$, thus providing new molecular tools to better appreciate the significance of $\mathrm{Hpa} 2$ in health and disease.

\section{MATERIALS AND METHODS}

\section{Antibodies and Reagents}

All reagents were purchased from Sigma unless specified otherwise. Anti-Hpa2 monoclonal antibodies were raised against $\mathrm{Hpa} 2$ protein purified from the conditioned medium of Hpa2-transfected HEK293 cells, essentially as described $(14,18)$. Briefly, Balb/C mice were immunized with the full-length Hpa2 protein. Hybridomas were obtained by routine procedures and were selected by ELISA using $\mathrm{Hpa} 2$ for coating. Several hybridomas that reacted positively with $\mathrm{Hpa} 2$ were selected for further characterization. Performance of the newly developed monoclonal antibodies is summarized in Table 1. Antisyndecan-1 (sc-5632), anti-syndecan-4 (sc-12766), anti-Erk (sc94), anti-phospho-Erk (sc-7383), anti-focal adhesion kinase (FAK; sc-932), and anti-Akt (sc-5298) antibodies were
TABLE 1 | Performance of anti-Hpa2 monoclonal antibodies.

\begin{tabular}{|c|c|c|c|c|c|c|}
\hline \multirow[t]{2}{*}{ Hybridoma } & \multirow{2}{*}{$\begin{array}{l}\text { Immuno- } \\
\text { blotting }\end{array}$} & \multirow[t]{2}{*}{ IF } & \multirow[t]{2}{*}{ IP } & \multicolumn{3}{|c|}{ Neutralizing: } \\
\hline & & & & $\begin{array}{c}\text { Cell } \\
\text { adhesion }\end{array}$ & $\begin{array}{c}\text { Cell } \\
\text { migration }\end{array}$ & $\begin{array}{c}\text { Cell } \\
\text { scattering }\end{array}$ \\
\hline $1 \mathrm{c7}$ & + & NT & - & no & no & yes \\
\hline $20 c 5$ & ++ & ++ & ++ & yes & yes & yes \\
\hline $21 b 9$ & + & NT & + & NT & yes & no \\
\hline $33 a 19$ & - & NT & + & yes & no & no \\
\hline 2B9 & ++ & NT & ++ & NT & NT & yes \\
\hline $5 G 4$ & + & - & NT & NT & NT & NT \\
\hline 6D11 & ++ & ++ & NT & yes & no & NT \\
\hline 6D12 & + & + & NT & yes & no & NT \\
\hline $6 F 7$ & ++ & - & NT & NT & NT & NT \\
\hline 7A6 & + & - & NT & NT & NT & NT \\
\hline 10G3 & + & + & NT & NT & NT & no \\
\hline
\end{tabular}

IF, Immunofluorescent staining.

IP, Immunoprecipitation.

NT, Not tested.

-: does not work.

+: work.

++ : work well.

purchased from Santa Cruz Biotechnology (Santa Cruz, CA). Anti-phospho-Akt and anti-phospho-FAK antibodies were purchased from Cell Signaling (Danvers, MA). Anti-vinculin and anti-actin antibodies were purchased from Sigma.

\section{Cells and Cell Culture}

U-87 MG glioma, SIHN-013 laryngeal carcinoma, A-549 lung adenocarcinoma and HEK-293 cells have been described previously $(14,15,19,20)$ and were grown in Dulbecco's modified Eagle's medium (Biological Industries, Beit Haemek, Israel) supplemented with $10 \%$ FCS and antibiotics. Human (5637, RT4) and mouse (MBT2-t50) bladder carcinoma, and U266 B-lymphoma cells have been described previously $(16,21-$ 24 ) and were grown in RPMI-1640 supplemented with 10\% FCS. Human umbilical vein-derived endothelial cells (HUVEC) were cultured in M199 medium containing 20\% FCS supplemented with $50 \mu \mathrm{g} / \mathrm{ml}$ bovine hypothalamus Endothelial Mitogen (ECGS) BT-203 (Biomedical Technologies, MA, USA) and 20 $\mu \mathrm{g} / \mathrm{ml}$ heparin. Cells were plated on dishes pre-incubated with $0.2 \%$ gelatin for $1 \mathrm{~h}$ at $37^{\circ} \mathrm{C}$, as described (25). HUVEC were not used beyond passage eight. Porcine aortic endothelial (PAE) cells were cultured in F-12 medium containing 10\% FCS, glutamine, and antibiotics, as described previously (26). MCF10A cells were kindly provided by Dr. Yosef Yarden (Weizmann Institute of Science, Rehovot, Israel) and were maintained in DMEM-F12 medium (1:1) supplemented with $0.1 \mu \mathrm{g} / \mathrm{ml}$ cholera toxin, 0.02 $\mu \mathrm{g} / \mathrm{ml}$ epidermal growth factor, $10 \mu \mathrm{g} / \mathrm{ml}$ insulin, $0.5 \mu \mathrm{g} / \mathrm{ml}$ hydrocortisone, $100 \mathrm{U} / \mathrm{ml}$ penicillin, $100 \mu \mathrm{g} / \mathrm{ml}$ streptomycin, and $5 \%$ horse serum, as described (27).

\section{Cell Adhesion}

Twenty-four-well plates were coated with $10 \mu \mathrm{g} / \mathrm{ml}$ of BSA, fibronectin, heparanase and $\mathrm{Hpa} 2$ for $18 \mathrm{~h}$ at $4^{\circ} \mathrm{C}$ (or $1 \mathrm{~h}$ at $37^{\circ} \mathrm{C}$ ). Cells were plated in medium supplemented with $10 \% \mathrm{FCS}$ and their adhesion, morphology and spreading properties were observed. After $1 \mathrm{~h}$, cells were washed, fixed with 4\% PFA, and 
photographed with or without crystal violet $(0.5 \%)$ staining. To examine the signaling associated with cell adhesion to heparanase/Hpa2, cells were plated in the absence or presence of heparin $(50 \mu \mathrm{g} / \mathrm{ml})$ or the indicated anti-Hpa2 monoclonal antibody $(30 \mu \mathrm{g} / \mathrm{ml})$. For biochemical analyses, cell extracts were prepared and subjected to immunoblotting with the indicated antibody or were fixed with cold methanol and subjected to immunofluorescent staining, as described $(14,28)$.

\section{Cell Migration}

Cells were plated in an ibidi wound scratch apparatus (Planegg, Germany) according to the manufacturer's instructions (Culture-Insert; ibidi), as described (16). Briefly, cells $\left(3 \times 10^{4}\right.$ in $0.1 \mathrm{ml}$ ) were seeded inside the apparatus. Once confluent, the inserts were removed, leaving a well-defined gap. Cell cultures were washed and changed to serum-free medium or medium containing $2 \%$ serum, and migration into the defined cell-free gap was inspected in the absence or presence of $10 \mu \mathrm{g} / \mathrm{ml}$ purified Hpa2. Cell migration into the gap was examined under light microscope and images were taken at the indicated time after $\mathrm{Hpa} 2$ addition without or with heparin $(50 \mu \mathrm{g} / \mathrm{ml})$ or the indicated $\mathrm{mAb}(30 \mu \mathrm{g} / \mathrm{ml})$.

\section{Cell Scattering}

Cells were plated in 12-well plates and were grown until discrete colonies were established. The indicated concentration of purified heparanase or $\mathrm{Hpa} 2$ proteins were then added in serum-free medium, alone or together with heparin $(50 \mu \mathrm{g} / \mathrm{ml})$, or the indicated anti-Hpa2 monoclonal antibody, and the morphology of cell colonies was observed after $24 \mathrm{~h}$.

\section{Protein Extraction and Immunoblotting}

Preparation of cell lysates and immunoblotting was performed essentially as described (14-16). Briefly, cell cultures were pretreated with $1 \mathrm{mM}$ orthovanadate for $10 \mathrm{~min}$ at $37^{\circ} \mathrm{C}$, washed twice with ice-cold PBS containing $1 \mathrm{mM}$ orthovanadate and scraped into lysis buffer $(50 \mathrm{mM}$ Tris- $\mathrm{HCl}$, $\mathrm{pH} 7.4,150 \mathrm{mM} \mathrm{NaCl}, 0.5 \% \mathrm{NP}-40,1 \mathrm{mM}$ orthovanadate, $1 \mathrm{mM}$ PMSF) containing a cocktail of proteinase inhibitors (Roche). Total cellular protein concentration was determined by the BCA assay according to the manufacturer's instructions (Pierce, Rockford, IL). Fifty $\mu$ g of cellular protein were resolved on SDS polyacrylamide gel, and immunoblotting was performed, as described (14-16).

\section{Flow Cytometry}

Cells were detached with $0.5 \mathrm{mM}$ EDTA, centrifuged at 1000 rpm for $4 \mathrm{~min}$, washed 3 times with washing buffer (PBS containing $0.1 \% \mathrm{FCS})$ and counted. Cells $\left(0.5 \times 10^{6}\right)$ were resuspended in PBS containing 1\% FCS and incubated with antisyndecan- 1 or -4 antibodies for $30 \mathrm{~min}$ on ice in light protected tubes. Negative control was incubated without the primary antibody. Cells were then washed 3 times with the above washing buffer and incubated as above with 488-conjugated secondary antibody, washed, and analyzed using a CyAn fluorescent activated cell sorter (Beckman coulter) and Summit software, as described $(28,29)$.

\section{RESULTS}

\section{Hpa2 Promotes HS-Dependent and -Independent Cell Adhesion}

We have reported previously that Hpa2 lacks the capacity to cleave HS, the hallmark of heparanase, but retains the ability to bind HS with high affinity (14). The consequences of this interaction have not been elucidated yet. To examine this aspect we purified Hpa2 to high purity levels (Supplementary Figure 1A) and evaluated the capacity of cells to adhere to dishes coated with Hpa2. This was envisioned based on previous reports that implicate latent heparanase and its HS-binding domains in cell adhesion (30-33). BSA and fibronectin were used as negative and positive controls, respectively, along with purified heparanase (34). We found that primary human umbilical vein endothelial cells (HUVEC; Figure 1A, second panels) and non-transformed HEK-293 cells (Figure 1A, upper panels) adhere and spread on Hpa2-coated dishes to a magnitude comparable to fibronectin and heparanase. Similarly, bladder carcinoma cells RT4 and MBT2-t50 adhered efficiently to dishes coated with Hpa2, heparanase, and fibronectin (Figure 1B, upper and third panels). Notably, adhesion of the bladder carcinoma cells to Hpa2-, and to a lesser extent to heparanasecoated dishes was attenuated markedly by heparin (Figure 1B, second and fourth panels). Cell adhesion to fibronectin was not affected by heparin (Figure 1B). Furthermore, heparanase and $\mathrm{Hpa} 2$ supported the adhesion of RPMI8266 (Supplementary Figure 1B) and U266 myeloma cells that normally grow in suspension, and this was similarly abrogated by heparin (Figure 1C), suggesting that the pro-adhesive properties of $\mathrm{Hpa} 2$ are mediated primarily by HS. Likewise, Hpa2 promoted the adhesion and spreading of U87 glioma cells (Figure 2A, upper panels). In striking contrast, nonetheless, adhesion of U87 cells to dishes coated with heparanase or $\mathrm{Hpa} 2$ was not affected by heparin (Figure 2A, lower panels). In order to ascertain this result we examined the capacity of a panel of newly developed anti-Hpa2 mAbs (Table 1) to interfere with the adhesion of U87 cells to dishes coated with Hpa2. We found that U87 cell adhesion was attenuated prominently by anti-Hpa $2 \mathrm{mAb} 20 \mathrm{c} 5,6 \mathrm{~d} 11$, and 6d12 (Figure 2B, lower panels) while other monoclonal antibodies (i.e., 1c7, 33a19) were less effective (Figure 2B; Table 1). These results critically support the notion that Hpa2 exerts HS-dependent and -independent pro-adhesive properties, depending on the cell type.

Given that adhesion of RT4 cells to Hpa2 was practically prevented by heparin whereas adhesion of U87 cells was heparinindependent (Figures 1B and 2A), we examined the occurrence of HSPG on their cell membrane. FACS analyses revealed that U266 cells express the highest levels of syndecan-1 (Figure 2C, upper panel), as would be expected for myeloma cells, whereas U87 cells express high levels of syndecan-4 (Figure 2C, lower panel). Seemingly, RT4 and U87 cells exhibited comparable levels of syndecan-1 and syndecan-4, suggesting that their adhesion to Hpa2 and its HS-dependency involve a more complex mechanism beyond mere interaction with HS.

To examine the signaling pathways associating with cell adhesion to Hpa2 we next plated U87 and HUVEC cells on 


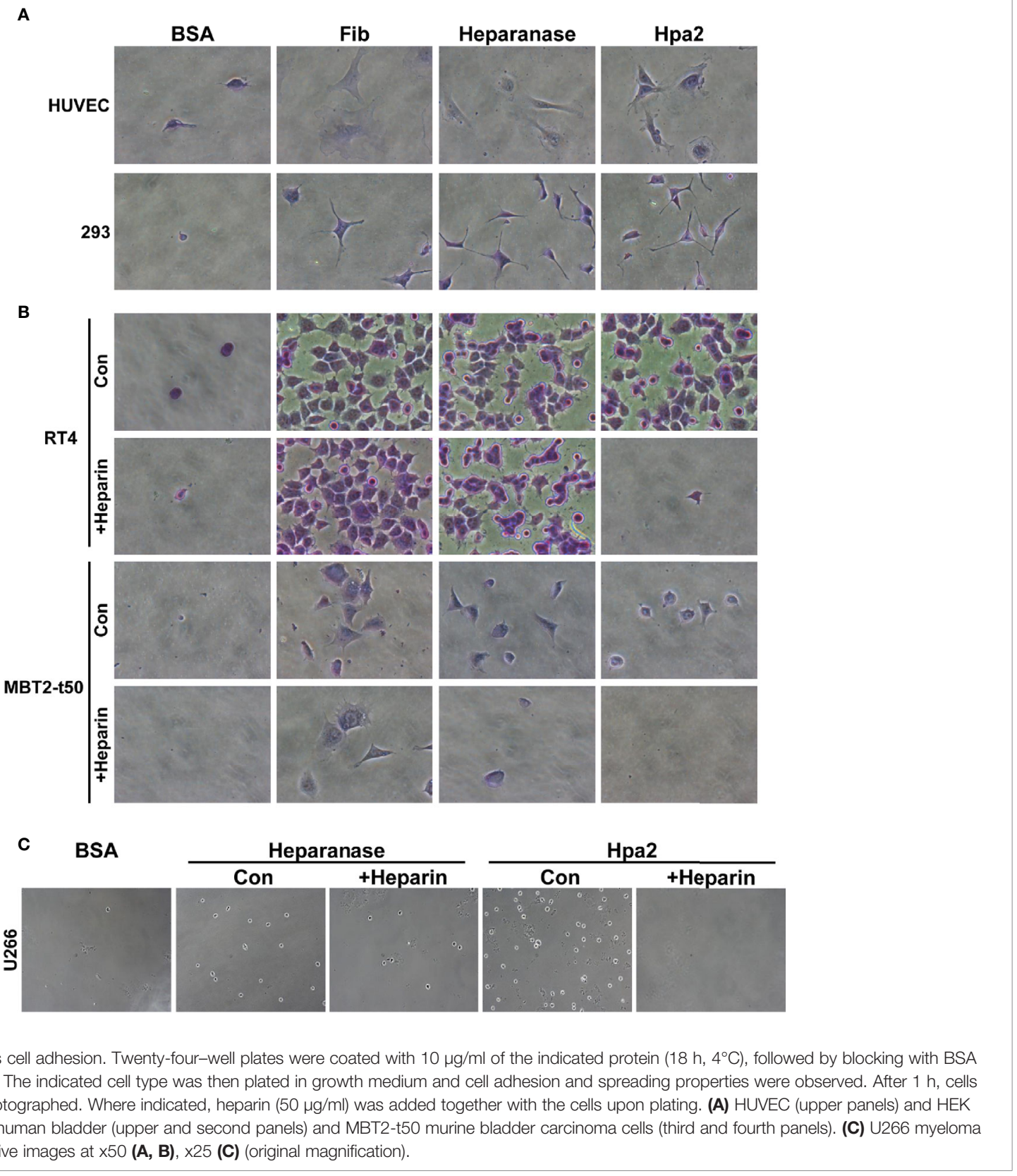

FIGURE 1 | Hpa2 promotes cell adhesion. Twenty-four-well plates were coated with $10 \mu \mathrm{g} / \mathrm{ml}$ of the indicated protein (18 $\mathrm{h}$, $\left.4^{\circ} \mathrm{C}\right)$, followed by blocking with BSA for $1 \mathrm{~h}$ at room temperature. The indicated cell type was then plated in growth medium and cell adhesion and spreading properties were observed. After $1 \mathrm{~h}$, cells were washed, fixed, and photographed. Where indicated, heparin (50 $\mathrm{\mu g} / \mathrm{ml})$ was added together with the cells upon plating. (A) HUVEC (upper panels) and HEK 293 (lower panels). (B) RT4 human bladder (upper and second panels) and MBT2-t50 murine bladder carcinoma cells (third and fourth panels). (C) U266 myeloma cells. Shown are representative images at x50 (A, B), x25 (C) (original magnification).

dishes coated with fibronectin, heparanase, or $\mathrm{Hpa} 2$ and cell extracts were subjected to immunoblotting. We found that cell adhesion to fibronectin was accompanied by increased phosphorylation of Erk (Fib; Figure 3A, upper panels), as would be expected. Interestingly, a comparable increase in Erk phosphorylation was noted in cells plated on heparanase and Hpa2 (Figure 3A, upper panels). Similarly, cell adhesion to Hpa2 was associated with increased phosphorylation of Akt (Figure 3A, left third panel) and focal adhesion kinase (FAK; Figure 3A, right third panel), signaling molecules highly implicated in integrin-mediated cell adhesion (35). Immunofluorescent staining of vinculin showed typical focal contacts in cells plated on fibronectin (Fib; Figure 3C). In contrast, cells plated on heparanase or $\mathrm{Hpa} 2$ appeared less spread and exhibited very few and immature focal contacts (Figure 3C). This suggests that induction of Erk, Akt and FAK phosphorylation by Hpa2 involves mechanism other than the classical integrin-mediated focal adhesion $(35,36)$, likely signaling by syndecans (37-39).

\section{Hpa2 Attenuates Cell Migration}

Applying the ibidi wound scratch apparatus we found that exogenous addition of Hpa2 attenuates the migration of 5637

(Figure 4A, upper vs middle panels), primary MCF10A human 
A

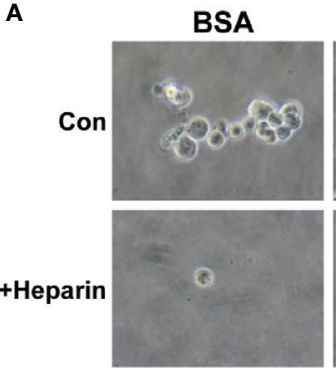

B
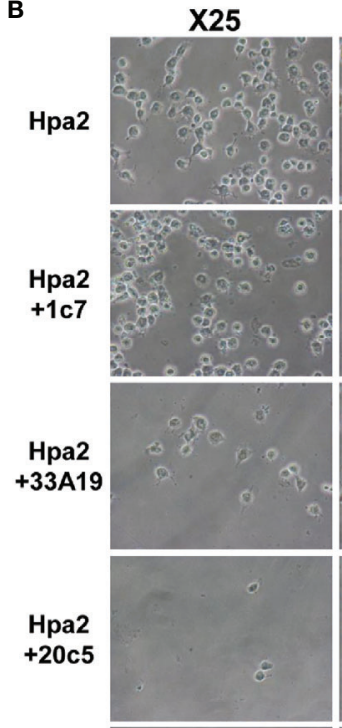

Hpa2

$+6 \mathrm{D11}$

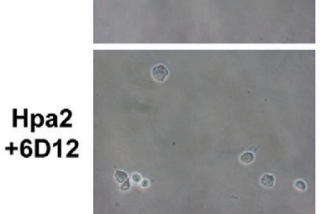

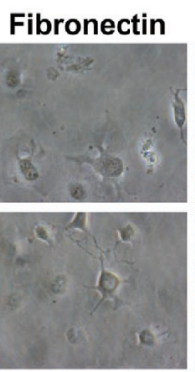

x50
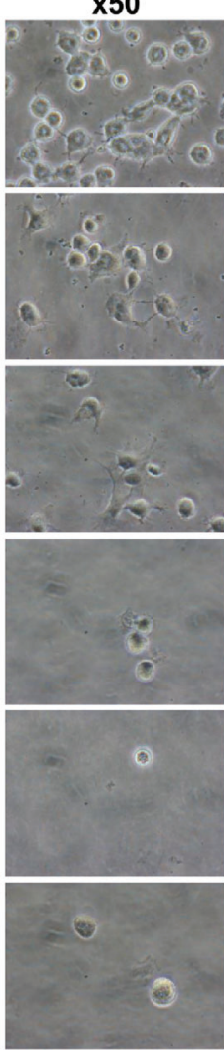
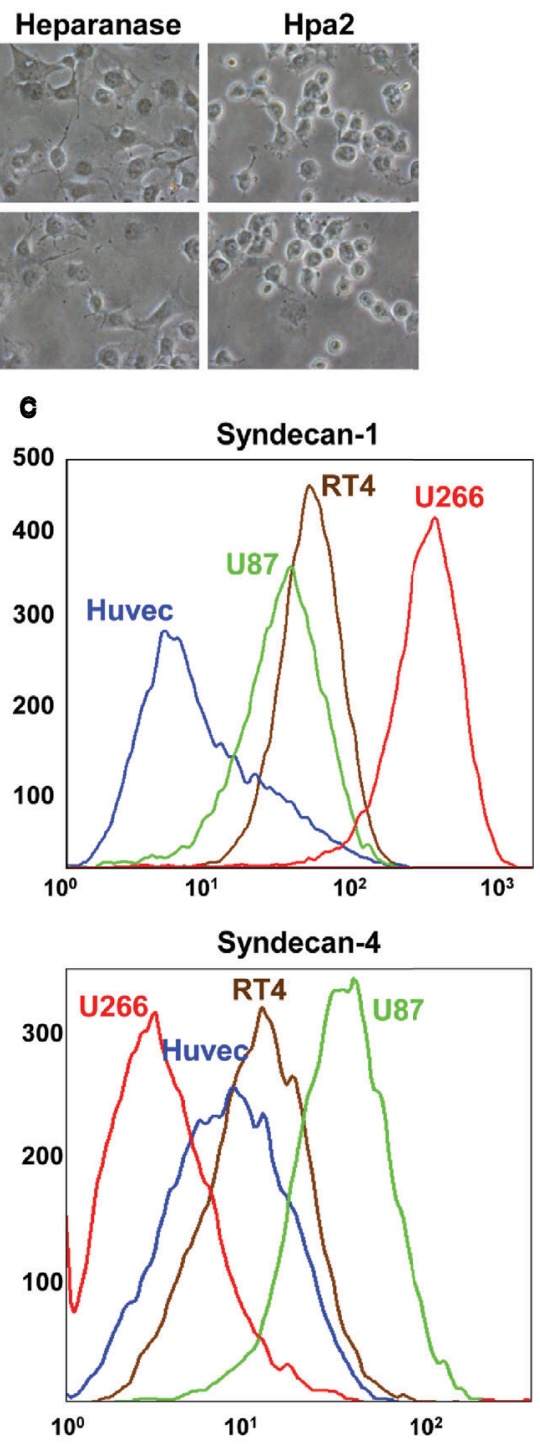

FIGURE 2 | (A) Adhesion of U87 glioma cells to Hpa2 is heparin-independent. U87 cells were plated on dishes coated with the indicated protein in the absence (upper panels) or presence (lower panels) of heparin $(50 \mu \mathrm{g} / \mathrm{ml})$. After $1 \mathrm{~h}$ cells were washed, fixed, and photographed. Shown are representative images at x50 (original magnification). (B) Inhibition of cell adhesion and spreading by anti-Hpa2 mAbs. U87 glioma cells were plated on Hpa2-coated dishes without (upper panel, Hpa2) or with the indicated mAb $(30 \mu \mathrm{g} / \mathrm{ml})$. Cells were also incubated with heparin $(50 \mu \mathrm{g} / \mathrm{ml})$. Cells were allowed to adhere and spread for $1 \mathrm{~h}$, washed and fixed. Shown are representative images at $x 25$ and x50 (original magnification). (C) FACS analysis. HUVEC, U87, RT4, and U266 cells were subjected to FACS analyses applying anti-syndecan-1 (upper panel) and anti-syndecan-4 (lower panel) antibodies.

breast (Supplementary Figure 1C), primary porcine endothelial (PAEC; Supplementary Figure 1D, upper panels), head and neck carcinoma SINH-013 (Supplementary Figure 1D, middle panel), and lung carcinoma A549 (Supplementary Figure 1D, lower panel) cells. Importantly, attenuation of cell migration by Hpa2 was compromised by heparin (Figure 4A, lower panels), implying that like cell adhesion, this function of Hpa2 is also HSdependent. We further examined our panel of anti-Hpa $2 \mathrm{mAbs}$ in the cell migration assay. We found that attenuation of 5637 cell migration by Hpa2 was abolished by mAbs 20c5 and 21B9 while other mAbs (i.e., 6D11, 6D12, 1c7, 6E10, 33A10) were not effective (Figure 4B; Table 1), laying more confidence that this effect is mediated by $\mathrm{Hpa} 2$.

\section{Hpa2 Promotes Cell Colonies Dissociation}

We have next examined the behavior of RT4 bladder carcinoma cells following the addition of our purified heparanase and Hpa2 proteins to the cell culture medium. RT4 cells grow in typical wellorganized colonies (Figure 5A, Control). Notably, the organization of cell colonies was disrupted following the 
A

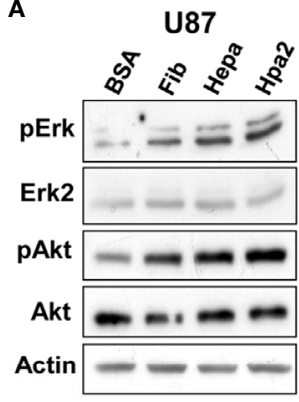

HUVEC

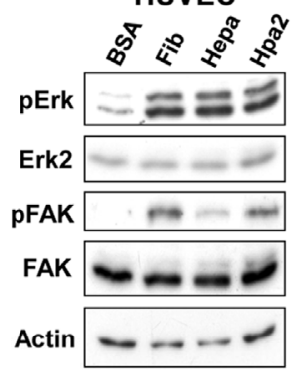

B
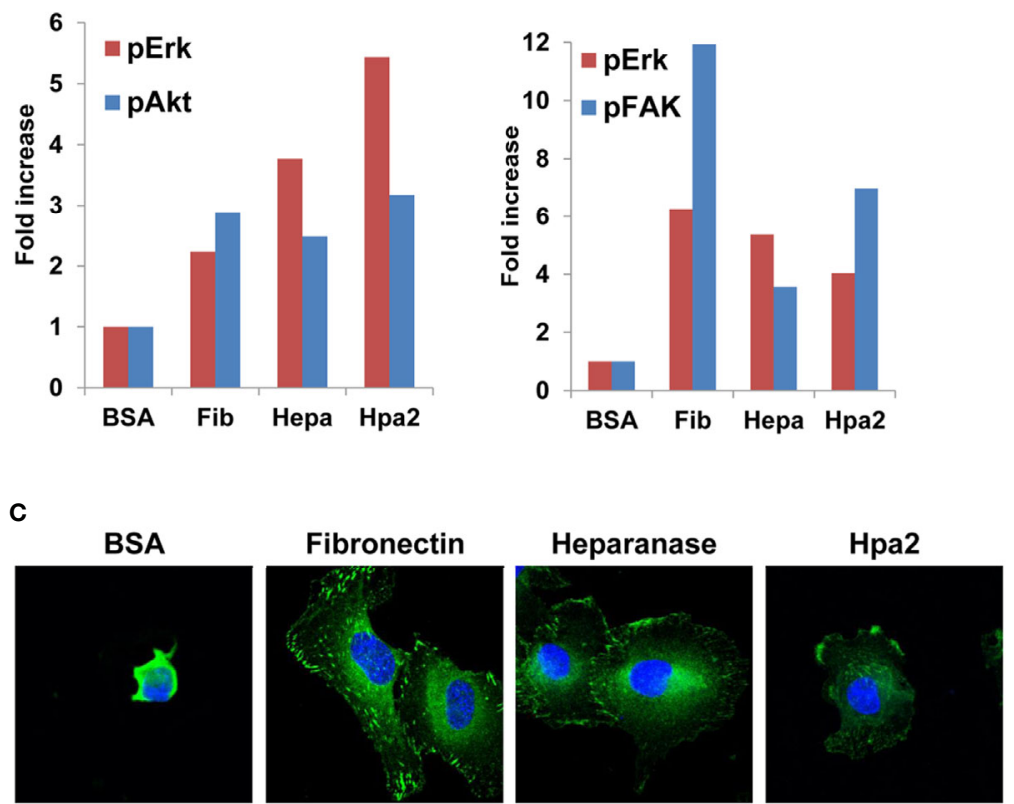

FIGURE 3 | Signaling. U87 (A, left) and HUVEC (A, right) cells were plated on dishes coated with the indicated protein for $1 \mathrm{~h}$. Cell extracts were then prepared from adherent and floating cells and subjected to immunoblotting applying antibodies directed against pErk (upper panel), Erk2 (second panels), pAkt (left third panel), Akt (left fourth panel), pFAK (right third panel), FAK (right fourth panel), or Actin (lower panels). Densitometry analysis of Erk, Akt, and FAK phosphorylation is shown graphically in (B). (C) Immufluorescent staining. HUVEC were plated on dishes coated with the indicated protein for $1 \mathrm{~h}$. Cells were then fixed with $4 \%$ PFA, followed by treatment with $0.5 \%$ triton $\times 100$ for 1 min. Cells were then subjected to immunofluorescent staining applying anti-vinculin antibody (green). Nuclear counterstaining is shown in blue. Note, focal adhesions in cells that adhered to fibronectin, and less so in cells that adhered to heparanase or Hpa2.

addition of heparanase. Unexpectedly, organization of cell colonies was disrupted also by Hpa2, leading to a scattered morphology (Figure 5A). Likewise, dissociation of cell colonies and induction of cell scattering were evident in non-transformed MDCK cells following exogenous addition of heparanase and Hpa2 (Supplementary Figure 1E). In laryngeal SINH-013 carcinoma cells, scattering and dissociation of cell colonies by $\mathrm{Hpa} 2$ were dose-dependent (Figure 5B, second panels) and exposure to $\mathrm{Hpa} 2$ for only $30 \mathrm{~min}$ was sufficient to elicit colony dissociation (Figure 5B, 30'). Furthermore, cell scattering by $\mathrm{Hpa} 2$ was prevented by heparin (Figure 5B, Hpa2+Heparin) and by $\mathrm{mAb} 1 \mathrm{c} 7$ (Figure 5B, Hpa2+1c7), a mAb shown previously to target the HS-binding domain of Hpa2 (15). Similarly, dissociation of RT4 colonies by Hpa2 was abrogated by anti-Hpa2 mAb 20c5, 6D12, 2B9, and 6E10 (Figure 6A upper and middle panels) while other mAbs had no effect (i.e., 33A19, 21B9, 10G3; Figure 6A, lower panels) (Table 1).

As noted previously (14), Hpa2 appeared tethered to the cell membrane following exogenous addition, co-localizing with syndecan-1 (Figure 6B), and failed to get internalized, suggesting that the effect of $\mathrm{Hpa} 2$ is initiated primarily at the cell membrane.

\section{DISCUSSION}

Unlike the intense research effort devoted to exploring the significance of heparanase in human diseases (40), very little attention was given to its close homolog, heparanase 2 (Hpa2). The emerging role of $\mathrm{Hpa} 2$ in a rare autosomal recessive 
A
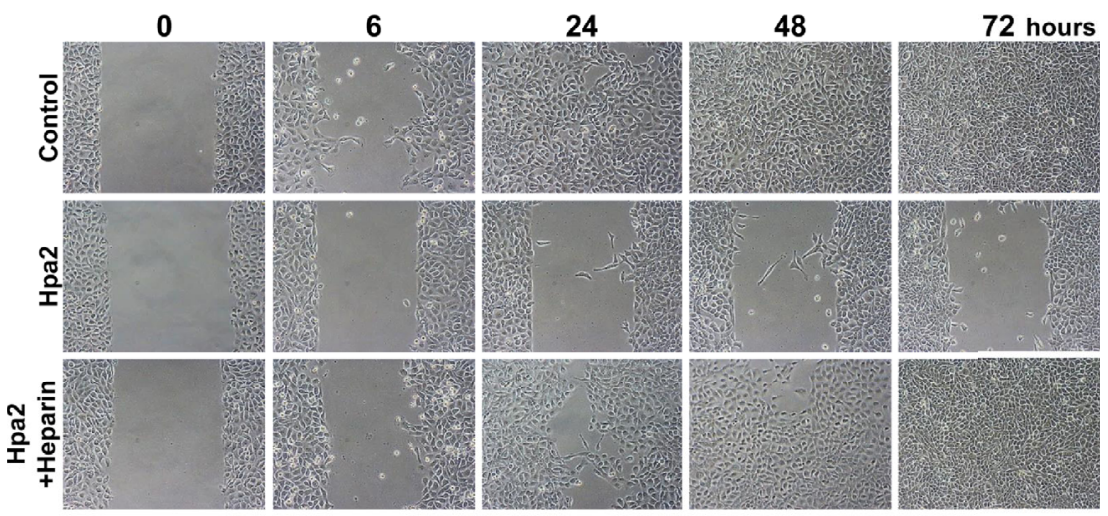

B
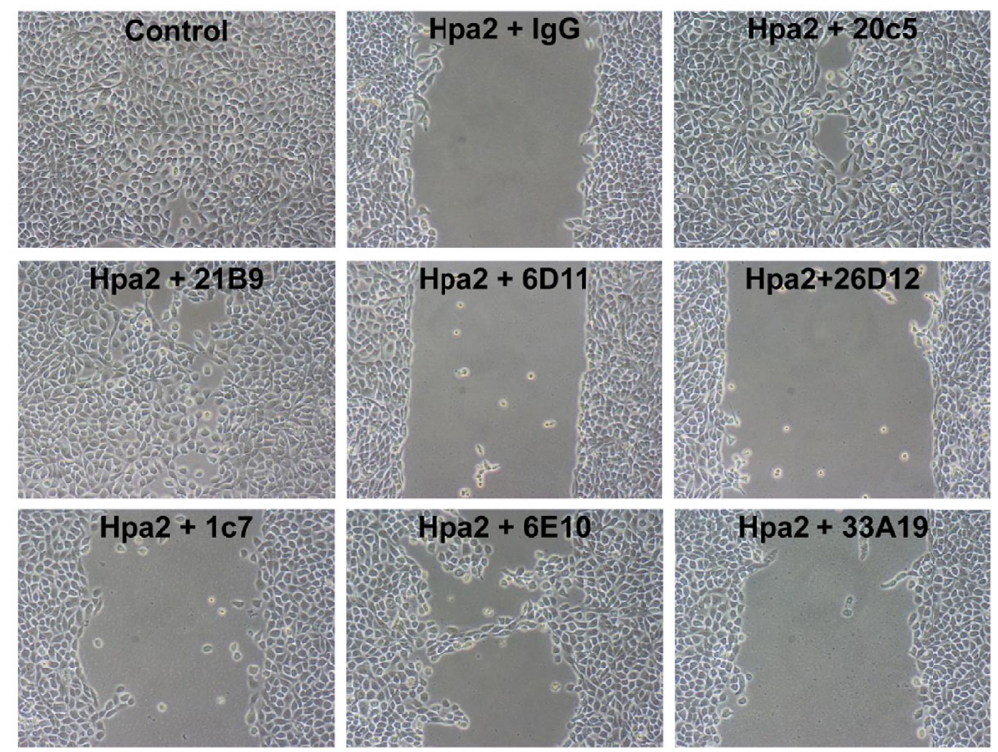

FIGURE 4 | Hpa2 attenuates cell migration. 5637 bladder carcinoma cells were plated in ibidi cell migration inserts apparatus (Planegg, Germany) until confluent. The barriers were then removed, cell cultures were washed and changed to serum-free medium, and migration into the defined cell-free gap was inspected in the

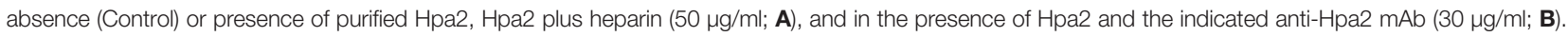

Shown are representative photomicrographs taken before (0), and 6, 24, 48, and $72 \mathrm{~h}$ after the addition of Hpa2 in the absence (Hpa2) and presence of heparin, control mouse lgG or the anti-Hpa2 mAbs. Note that cell migration and wound closure is attenuated prominently by exogenous Hpa2, and this effect is reversed by some of the anti-Hpa2 mAbs, and heparin. Shown are representative images at x50 (original magnification).

congenital disease called urofacial syndrome (UFS) (41-43), clearly indicates that $\mathrm{Hpa} 2$ is not a pseudogene but rather a gene coding for an important protein. Most recently, it was reported that $\mathrm{Hpa} 2$ levels are prominently decreased in critically ill Covid-19 patients, resulting in high heparanase to Hpa2 ratio (44). Accordingly, shedding of syndecan-1 was increased, while the thickness of the endothelial glycocalyx that contributes to the maintenance of vascular homeostasis was markedly reduced in Covid-19 patients (44). This may suggest that Hpa2 functions to preserve and protect the vasculature, in line with the notion that Covid-19 is a vascular disease (45). This may turn very important in other diseases that involve disruption of the glycocalyx such as sepsis (46). Indeed, Hpa2 was found to protect the vascular endothelium from LPS and in conditions of sepsis. Hpa2overexpressing endothelial cells were protected against LPSmediated loss of cell-cell contacts and administration of purified $\mathrm{Hpa} 2$ to mice resulted in decreased plasma levels of TNF $\alpha$ and IL- 6 after LPS injection (47).

In line with this notion is the observed decrease in Hpa2 expression in cancer patients $(14,16,17,48,49)$, implying that $\mathrm{Hpa} 2$ not only protects the vascular endothelium but also the epithelium. Indeed, cancer patients that express high levels of Hpa2 were diagnosed mostly as low-grade, expressed higher levels of cytokeratins, and survived for a longer time (14-17, 50, 51). Furthermore, overexpression of $\mathrm{Hpa} 2$ resulted in smaller tumors endowed with reduced vascular density (blood and 
A
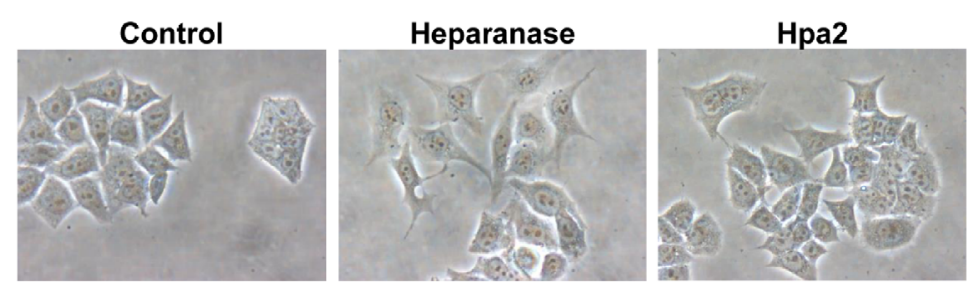

B
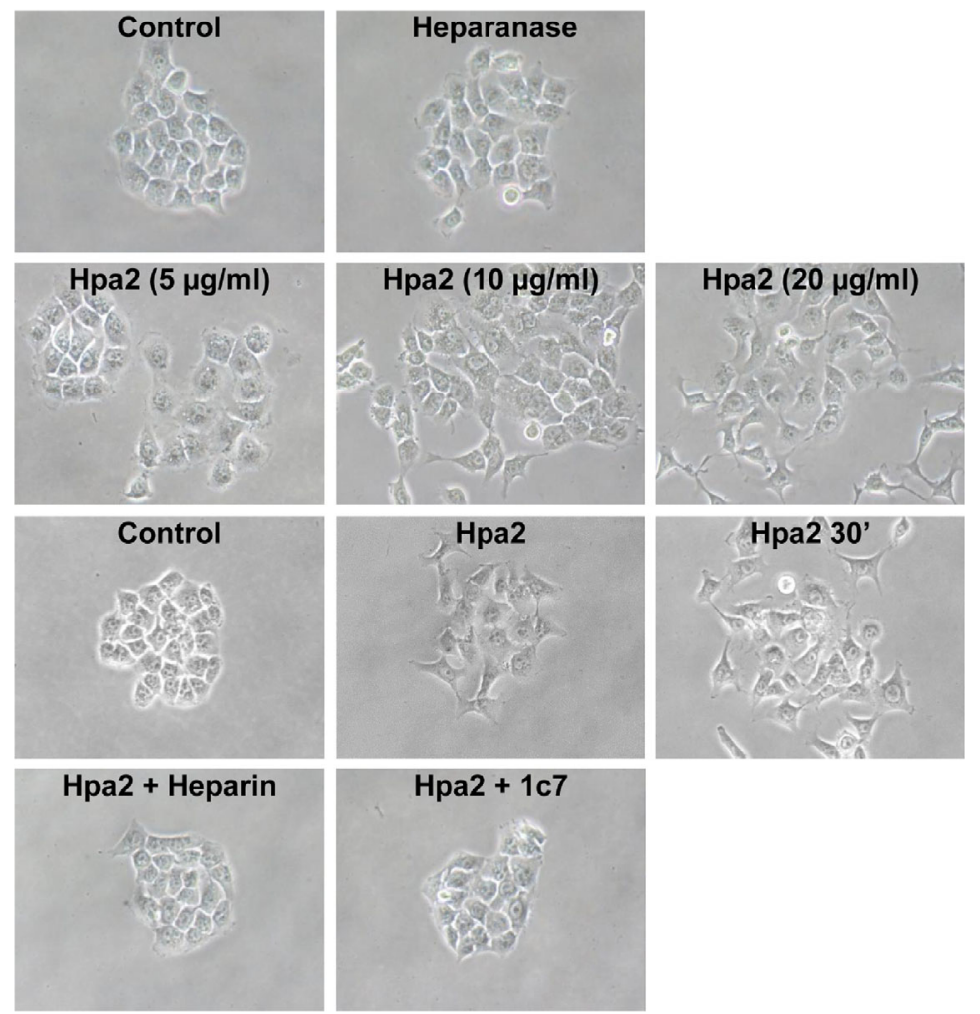

FIGURE 5 | Cell scattering. (A) RT4 bladder carcinoma cells were allowed to grow for 2-3 days until cell colonies were formed. Heparanase or Hpa2 (10 4 g/ml) were then added and colonies morphology was examined after $24 \mathrm{~h}$ vs. control (Control) untreated cells. (B) SINH-013 laryngeal carcinoma cells were similarly treated with heparanase or the indicated concentration of $\mathrm{Hpa2}$ (second panels), or were treated with Hpa2 for 30 min; Medium was then removed, the cell culture washed and replaced with fresh medium without Hpa2 (third panels, Hpa2 30'). Colony morphology and cell scattering was examined after $24 \mathrm{~h}$ vs. cultures untreated (Control) or treated with $\mathrm{Hpa} 2$ (third panels). Cell scattering was similarly examined in cell cultures treated with $\mathrm{Hpa} 2$ in the presence of heparin (50 $\mu \mathrm{g} / \mathrm{ml}$; Hpa2+Heparin) or mAb $1 \mathrm{c} 7$ (30 $\mathrm{gg} / \mathrm{ml}$; Hpa2+1c7) (lower panels). Shown are representative images at x100 (original magnification).

lymphatic) (15), thus expending the role of Hpa2 in vascular biology.

The capacity of Hpa2 to inhibit heparanase enzymatic activity (14) implies that Hpa2 functions as an endogenous inhibitor of heparanase, leading to evaluation of heparanase to $\mathrm{Hpa} 2$ ratio as an important parameter in diseases (44). Hpa2, nonetheless, can function in a manner that seems heparanase-independent. A prime suspect underlying this aspect is the capacity of $\mathrm{Hpa} 2$ to interact with HS with high affinity (14), resulting in clustering of cell membrane HSPG (i.e., syndecans) and likely activation of signaling cascades. Thus, while Hpa2 lacks HS-degrading activity typical of heparanase, its ability to bind HS is preserved. In fact,
Hpa2 exhibits a 10-fold higher affinity to HS than heparanase (14), but the biological significance of this interaction was unclear. Utilizing a highly purified $\mathrm{Hpa} 2$ protein we show here, for the first time, that Hpa2 directs cell adhesion and motility and that these effects, to a large extent, are HS-dependent. Our results demonstrate that Hpa2 attenuates the migration of nontransformed (PAEC, MCF10A) and malignant (5637, SINH013, A549) cells (Figure 4; Supplementary Figures 1C, D). Importantly, attenuated cell migration by $\mathrm{Hpa} 2$ was reversed once heparin was added together with Hpa2 (Figure 4A), preventing its interaction with cell membrane HSPG (14). Possibly, the added Hpa2 decreases the heparanase to Hpa2 
A
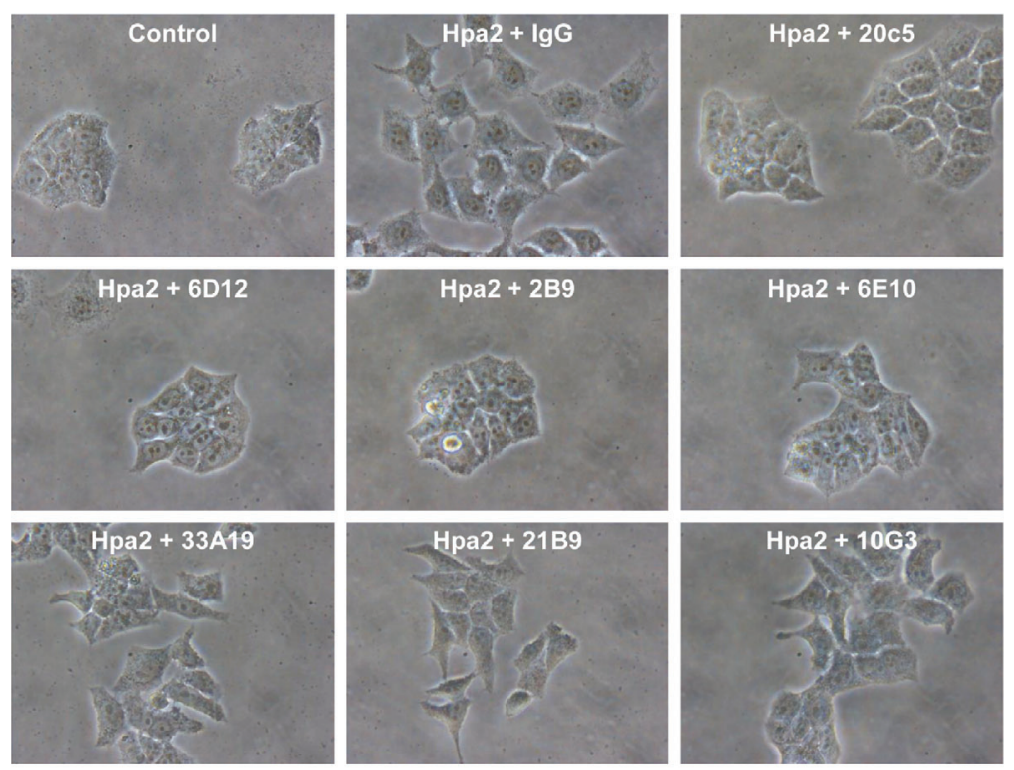

B
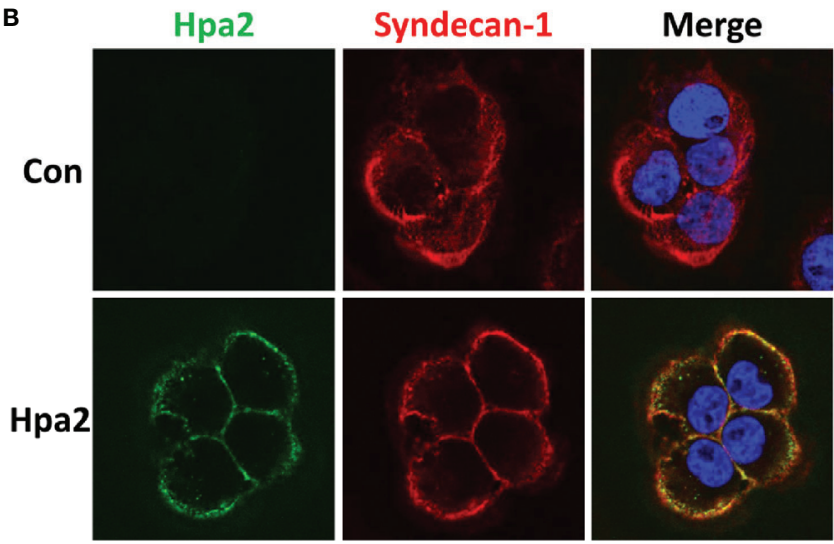

FIGURE 6 | (A) Anti-Hpa2 mAbs neutralize the scattering capacity of Hpa2. RT4 cells were allowed to establish colonies and were then treated with Hpa2 $(10 \mu \mathrm{g} / \mathrm{ml})$ in the presence of control mouse lgG or the indicated anti-Hpa2 mAb (30 $\mu \mathrm{g} / \mathrm{ml})$. Colony morphology was examined after $24 \mathrm{~h}$. Shown are representative images at $\times 100$ (original magnification). (B) Immunofluorescent staining. SIHN-013 cells were left untreated (Control; upper panels) or were incubated with Hpa2 (5 $\mathrm{gg} / \mathrm{ml}$ ) for 30 min (lower panels). Cells were then washed, fixed, and subjected to immunofluorescent staining applying anti-Hpa2 (20c5; green) and anti-syndecan-1 (red) antibodies. Merge images are shown in the right panels. Note co-localization of Hpa2 and syndecan-1 on the cell membrane.

ratio and antagonizes the pro-migratory effect of heparanase (25, 33 ), while heparin tilts this ratio back in favor of heparanase. However, given that heparin is a strong inhibitor of heparanase enzymatic activity (52), the increased cell migration following addition of heparin is not likely to be attributed to heparanase. Instead, exogenous Hpa2 likely elicits signaling from the cell membrane that affects cell motility which is prevented by heparin. The nature of the signal transduction involved is unclear but may be related to the signaling evoked by Hpa2mediated cell adhesion (Figure 3).

Previous studies have shown that heparanase not only promotes cell invasion, associated with its well-established pro- metastatic properties but also promotes cell adhesion and migration. Unlike the pro-invasive properties of heparanase, increased cell adhesion and migration appeared enzymatic activity-independent $(25,30,31,53)$. Instead, increased cell adhesion and spreading by heparanase likely involves signaling aspects due, in part, to clustering of cell membrane HSPG. This was concluded because cell adhesion and spreading was promoted also by a peptide derived from the HS-binding domain (KKDC) of heparanase, involving activation of Rac (31). Similarly, primary and transformed cells readily adhere to dishes coated with Hpa2 in an HS-dependent manner that was inhibited by heparin (Figures 1B, C). Curiously, adhesion of 
some cell lines (i.e., U87 and HUVEC) to Hpa2 was not attenuated by heparin (Figures 2A, B and data not shown), which cannot be explained simply by the abundance of syndecan-1 and -4 on the cell membrane (Figure 2C). This suggests a more complex mechanism that possibly involves other Hpa2-binding protein(s). According to this notion, such Hpa2binding protein(s) co-operate with HSPG (or function independent of HSPG) to mediate cell adhesion and signal transduction. If such a putative protein is highly abundant in cells (i.e., U87 glioma), and exhibits a very high affinity to Hpa2, than interaction with HS may become secondary and thus not affected by heparin. Alternatively, specific disaccharide composition, sequences and modifications of HS may underlie the differential responses to heparin. Studies towards these possibilities are underway. Interestingly, the phosphorylation of Erk, FAK, and Akt was increased prominently in cells plated on Hpa2, comparable in magnitude to their phosphorylation in cells plated on fibronectin (Figure 3). However, while typical adherent junctions were evident in cells plated on fibronectin, signifying classical integrin-mediated cell adhesion, cells plated on $\mathrm{Hpa} 2$ did not present such structures (Figure 3C), favoring HSPG-mediated adhesion $(39,54,55)$.

Modulation of Erk phosphorylation by Hpa2 was observed in two other experimental settings. A marked increase of Erk phosphorylation was noted in Xenopus embryos in which Hpa2 expression was knocked-out vs control wt embryos, suggesting that in normal development Hpa2 attenuates Erk phosphorylation coinciding with early stages of embryo motility (56). Moreover, the protective effect of Hpa2 against LPS-mediated endothelial cell damage was associated with reduced Erk phosphorylation (47). This suggests that Hpa2 can modulate Erk phosphorylation up or down depending on the system and experimental setting being investigated. Notably, application of the $1 \mathrm{C} 7$ antibody and thus displacement of the protein from cell surface HS glycocalyx structures reversed the protective effect of $\mathrm{Hpa} 2$, resulting in strong activation of the LPS response (47). Collectively, these results suggest that $\mathrm{Hpa} 2$ modulates Erk phosphorylation, and this function likely involves cell surface HSPG. Thus, attenuated cell migration following exogenous addition of Hpa2 may result from decreased phosphorylation of Erk and related signaling molecules. More research is required to reveal the signaling cascades elicited by $\mathrm{Hpa} 2$, and studies focusing on this direction are currently underway.

Unexpectedly, exogenous addition of $\mathrm{Hpa} 2$ resulted also in the disruption of well-organized cell colonies. Moreover, exposure of the cell colonies to Hpa2 for only 15 (not shown) and 30 min was sufficient to elicit the scattering effect (Figure 5B, 30 '), indicating that signaling, rather than gene transcription, is involved. At a first glance, the scattering effect looked surprising and counterintuitive to the notion of $\mathrm{Hpa} 2$ as a tumor suppressor (14-17). However, given the role of Hpa2 in development (56) and the tight coordination of cell motility during developmental processes, decreased (Figure 4) and enhanced (Figure 5) cell motility are two sides of the same coin. Thus, Hpa2 expression is likely tightly regulated. Mechanisms that regulate $\mathrm{Hpa} 2$ expression have not been elucidated yet and are currently under investigation.

Notably, the ability of Hpa2 to modulate cell adhesion, migration and scattering were reversed by anti-Hpa2 mAbs, thus laying confidence that these are truly effects of Hpa2. Importantly, $\mathrm{mAb} 20 \mathrm{c} 5$ was noted to reverse the effects of $\mathrm{Hpa} 2$ on cell adhesion (Figure 2B), cell migration (Figure 4B), and cell scattering (Figure 6A) (Table 1), suggesting that its epitope is critical for $\mathrm{Hpa} 2$ functions. Elucidating the sequence of this epitope employing peptide mapping or co-crystallization of $\mathrm{Hpa} 2$ with this and other anti-Hpa2 functional mAbs (i.e., 1c7) will enable the mapping of functional domains within the Hpa2 protein. This would greatly improve our understating of Hpa2 functional domains, including its HS-binding motif. Notably, HS-binding domains have been characterized in heparanase (57) but are not conserved in Hpa2 (58). Applying the ClusPro server, Coombe and Gandhi (58) modeled a predicted crystal structure of Hpa2 to the crystal structure of pro-heparanase (59). Interestingly the analysis revealed that the most favored region for binding heparin lies within the C-terminus of Hpa2 (58). More specifically, the residues predicted by the ClusPro docking analysis to mediate the binding of $\mathrm{Hpa} 2$ to $\mathrm{HS}$ were $\mathrm{Gln}^{524}$, $\operatorname{Arg}^{466}, \operatorname{Arg}^{508}, \mathrm{Lys}^{509}, \mathrm{Lys}^{510}, \mathrm{Lys}^{512}, \mathrm{Arg}^{561}, \mathrm{Arg}^{564}, \mathrm{Arg}^{567}$, and $\mathrm{Thr}^{568}$, different from previous prediction (13). Studies directed toward identifying functional domains of $\mathrm{Hpa} 2$ are currently in progress.

Taken together, we describe previously unrecognized functions of Hpa2, profoundly affecting cell adhesion and motility. Cell migration is critical in diverse biological processes, ranging from development to wound healing, metastasis, and immune responses, all of which require the orchestrated movement of cells in particular directions to specific locations. The capacity of $\mathrm{Hpa} 2$ to direct cell motility suggests that this protein plays a significant role in diverse biological settings, as critically emerged from the lethal phenotype of Hpa2-mutant mice $(43,60)$. These results strongly encourage an in-depth investigation of $\mathrm{Hpa} 2$, toward elucidating its role in health and disease.

\section{DATA AVAILABILITY STATEMENT}

The original contributions presented in the study are included in the article/Supplementary Material. Further inquiries can be directed to the corresponding author.

\section{AUTHOR CONTRIBUTIONS}

Conception and design: IV, NI. Development of methodology: MG-C, SF, GA. Acquisition of data: MG-C. Analysis and interpretation of data: MG-C, NI, IV. Writing, review, and/or revision of the manuscript: MG-C, NI, IV. Study supervision: IV. All authors contributed to the article and approved the submitted version. 


\section{FUNDING}

These studies were generously supported by research grants awarded by the Israel Science Foundation (grant 1021/19); the United States-Israel Binational Science Foundation (BSF); and the Israel Cancer Research Fund (ICRF). IV is a Research Professor of the ICRF.

\section{SUPPLEMENTARY MATERIAL}

The Supplementary Material for this article can be found online at: https://www.frontiersin.org/articles/10.3389/fonc.2020. 627463/full\#supplementary-material

\section{REFERENCES}

1. Khanna M, Parish CR. Heparanase: Historical aspects and future perspectives. Adv Exp Med Biol (1221) 2020):71-96. doi: 10.1007/978-3-030-34521-1_3

2. Mayfosh AJ, Baschuk N, Hulett MD. Leukocyte Heparanase: A double-edged sword in tumor progression. Front Oncol (2019) 9:331. doi: 10.3389/ fonc.2019.00331

3. Vlodavsky I, Singh P, Boyango I, Gutter-Kapon L, Elkin M, Sanderson RD, et al. Heparanase: From basic research to therapeutic applications in cancer and inflammation. Drug Resist Updates (2016) 29:54-75. doi: 10.1016/ j.drup.2016.10.001

4. Purushothaman A, Sanderson RD. Heparanase: A dynamic promoter of myeloma progression. Adv Exp Med Biol (2020) 1221:331-49. doi: 10.1007/ 978-3-030-34521-1_12

5. Sanderson RD, Bandari SK, Vlodavsky I. Proteases and glycosidases on the surface of exosomes: Newly discovered mechanisms for extracellular remodeling. Matrix Biol (2019) 75-76:160-9. doi: 10.1016/j.matbio.2017.10.007

6. Cohen-Kaplan V, Ilan N, Vlodavsky I. Heparanase loosens E-cadherinmediated cell-cell contact via activation of Src. Front Oncol (2020) 10:2. doi: $10.3389 /$ fonc.2020.00002

7. Koganti R, Suryawanshi R, Shukla D. Heparanase, cell signaling, and viral infections. Cell Mol Life Sci (2020) 77(24):5059-77. doi: 10.1007/s00018-02003559-y

8. Rivara S, Milazzo FM, Giannini G. Heparanase: a rainbow pharmacological target associated to multiple pathologies including rare diseases. Future Med Chem (2016) 8(6):647-80. doi: 10.4155/fmc-2016-0012

9. Sanderson RD, Elkin M, Rapraeger AC, Ilan N, Vlodavsky I. Heparanase regulation of cancer, autophagy and inflammation: new mechanisms and targets for therapy. FEBS J (2017) 284(1):42-55. doi: 10.1111/febs.13932

10. Dredge K, Brennan TV, Hammond E, Lickliter JD, Lin L, Bampton D, et al. A Phase I study of the novel immunomodulatory agent PG545 (pixatimod) in subjects with advanced solid tumours. Br J Cancer (2018) 118(8):1035-41. doi: 10.1038/s41416-018-0006-0

11. Galli M, Chatterjee M, Grasso M, Specchia G, Magen H, Einsele H, et al. Phase I study of the heparanase inhibitor roneparstat: an innovative approach for ultiple myeloma therapy. Haematologica (2018) 103(10):e469-72. doi: 10.3324/haematol.2017.182865

12. Guimond SE, Mycroft-West CJ, Gandhi NS, Tree JA, Buttigieg KR, Coombes $\mathrm{N}$, et al. Pixatimod (PG545), a clinical-stage heparan sulfate mimetic, is a potent inhibitor of the SARSCoV-2 virus. bioRxiv (2020). doi: 10.1101/ 2020.06.24.169334

13. McKenzie E, Tyson K, Stamps A, Smith P, Turner P, Barry R, et al. Cloning and expression profiling of $\mathrm{Hpa} 2$, a novel mammalian heparanase family member. Biochem Biophys Res Commun (2000) 276(3):1170-7. doi: 10.1006/bbrc.2000.3586

14. Levy-Adam F, Feld S, Cohen-Kaplan V, Shteingauz A, Gross M, Arvatz G, et al. Heparanase 2 interacts with heparan sulfate with high affinity and inhibits heparanase activity. J Biol Chem (2010) 285(36):28010-9. doi: 10.1074/jbc.M110.116384
Supplementary Figure 1 | (A) Purified Hpa2. (B) RPMl 8226 myeloma cells were plated on dishes coated with BSA, heparanase, or Hpa2. After 1 hour, the medium was removed and attached cells were visualized. Shown are representative images at $\times 100$ (original magnification). (C, D) Cell migration. Porcine aortic endothelial (PAEC, upper panels), SIHN-013 laryngeal carcinoma (second panels), and A549 lung carcinoma (third panels) cells were plated in ibidi cell migration inserts apparatus (Planegg, Germany) until confluent. The barrier was then removed, cell cultures were washed and changed to serum-free medium or medium containing $2 \%$ serum, and migration into the defined cell-free gap was inspected in the absence (Con, left) or presence of $10 \mu \mathrm{g} / \mathrm{ml}$ purified Hpa2 (right). Migration of non-transformed MCF10A human breast cells in the absence (Control) or presence of EGF $(20 \mathrm{ng} / \mathrm{ml})$ alone or EGF and Hpa2 is shown in (C). Shown are representative photomicrographs taken 24 hours after the addition of Hpa2. (E) Cell scattering. MDCK cells were allowed to grow for 2-3 days until cell colonies were formed. Heparanase or Hpa2 $(10 \mu \mathrm{g} / \mathrm{ml})$ was then added and colonies morphology was examined after 24 hours vs control (Con) untreated cells. Shown are representative images at x100 (original magnification).

15. Gross-Cohen M, Feld S, Doweck I, Neufeld G, Hasson P, Arvatz G, et al. Heparanase 2 attenuates head and neck tumor vascularity and growth. Cancer Res (2016) 76(9):2791-801. doi: 10.1158/0008-5472.CAN-15-1975

16. Gross-Cohen M, Feld S, Naroditsky I, Nativ O, Ilan N, Vlodavsky I. Heparanase 2 expression inversely correlates with bladder carcinoma grade and stage. Oncotarget (2016) 7(16):22556-65. doi: 10.18632/oncotarget.8003

17. Vlodavsky I, Gross-Cohen M, Weissmann M, Ilan N, Sanderson RD. Opposing functions of heparanase- 1 and heparanase-2 in cancer progression. Trends Biochem Sci (2018) 43(1):18-31. doi: 10.1016/ j.tibs.2017.10.007

18. Gingis-Velitski S, Ishai-Michaeli R, Vlodavsky I, Ilan N. Anti-heparanase monoclonal antibody enhances heparanase enzymatic activity and facilitates wound healing. FASEB J (2007) 21:3986-93. doi: 10.1096/fj.07-8866com

19. Barash U, Spyrou A, Liu P, Vlodavsky E, Zhu C, Luo J, et al. Heparanase promotes glioma progression via enhancing CD24 expression. Intl J Cancer (2019) 145(6):1596-608. doi: 10.1002/ijc.32375

20. Katz A, Barash U, Boyango I, Feld S, Zohar Y, Hammond E, et al. Patient derived xenografts (PDX) predict an effective heparanase-based therapy for lung cancer. Oncotarget (2018) 9(27):19294-306. doi: 10.18632/ oncotarget.25022

21. Barash U, Zohar Y, Wildbaum G, Beider K, Nagler A, Karin N, et al. Heparanase enhances myeloma progression via CXCL10 downregulation. Leukemia (2014) 28(11):2178-87. doi: 10.1038/leu.2014.121

22. Elkin M, Reich R, Nagler A, Aingorn E, Pines M, de-Groot N, et al. Inhibition of matrix metalloproteinase-2 expression and bladder carcinoma metastasis by halofuginone. Clin Cancer Res (1999) 5(8):1982-8.

23. Weissmann M, Arvatz G, Horowitz N, Feld S, Naroditsky I, Zhang Y, et al. Heparanase-neutralizing antibodies attenuate lymphoma tumor growth and metastasis. Proc Natl Acad Sci U States America (2016) 113(3):704-9. doi: $10.1073 /$ pnas. 1519453113

24. Weissmann M, Bhattacharya U, Feld S, Hammond E, Ilan N, Vlodavsky I. The heparanase inhibitor PG545 is a potent anti-lymphoma drug: Mode of action. Matrix Biol (2019) 77:58-72. doi: 10.1016/j.matbio.2018.08.005

25. Gingis-Velitski S, Zetser A, Flugelman MY, Vlodavsky I, Ilan N. Heparanase induces endothelial cell migration via protein kinase B/Akt activation. J Biol Chem (2004) 279(22):23536-41. doi: 10.1074/jbc.M400554200

26. Gluzman-Poltorak Z, Cohen T, Shibuya M, Neufeld G. Vascular endothelial growth factor receptor-1 and neuropilin-2 form complexes. J Biol Chem (2001) 276(22):18688-94. doi: 10.1074/jbc.M006909200

27. Boyango I, Barash U, Naroditsky I, Li JP, Hammond E, Ilan N, et al. Heparanase cooperates with Ras to drive breast and skin tumorigenesis. Cancer Res (2014) 74:4504-14. doi: 10.1158/0008-5472.CAN-13-2962

28. Bhattacharya U, Gutter-Kapon L, Kan T, Boyango I, Barash U, Yang SM, et al. Heparanase and Chemotherapy Synergize to Drive Macrophage Activation and Enhance Tumor Growth. Cancer Res (2020) 80(1):57-68. doi: 10.1158/ 0008-5472.CAN-19-1676

29. Gutter-Kapon L, Alishekevitz D, Shaked Y, Li JP, Aronheim A, Ilan N, et al. Heparanase is required for activation and function of macrophages. Proc Natl 
Acad Sci U States America (2016) 113(48):E7808-17. doi: 10.1073/ pnas.1611380113

30. Goldshmidt O, Zcharia E, Cohen M, Aingorn H, Cohen I, Nadav L, et al. Heparanase mediates cell adhesion independent of its enzymatic activity. FASEB J (2003) 17(9):1015-25. doi: 10.1096/fj.02-0773com

31. Levy-Adam F, Feld S, Suss-Toby E, Vlodavsky I, Ilan N. Heparanase facilitates cell adhesion and spreading by clustering of cell surface heparan sulfate proteoglycans. PloS One (2008) 3(6):e2319. doi: 10.1371/journal.pone.0002319

32. Levy-Adam F, Ilan N, Vlodavsky I. Tumorigenic and adhesive properties of heparanase. Semin Cancer Biol (2010) 20(3):153-60. doi: 10.1016/ j.semcancer.2010.06.005

33. Zetser A, Bashenko Y, Miao H-Q, Vlodavsky I, Ilan N. Heparanase affects adhesive and tumorigenic potential of human glioma cells. Cancer Res (2003) 63(22):7733-41.

34. Blich M, Golan A, Arvatz G, Sebbag A, Shafat I, Sabo E, et al. Macrophage activation by heparanase is mediated by TLR- 2 and TLR- 4 and associates with plaque progression. Arteriosc Thromb Vasc Biol (2013) 33:e56-65. doi: 10.1161/ATVBAHA.112.254961

35. Winograd-Katz SE, Fassler R, Geiger B, Legate KR. The integrin adhesome: from genes and proteins to human disease. Nat Rev Mol Cell Biol (2014) 15 (4):273-88. doi: 10.1038/nrm3769

36. Moreno-Layseca P, Streuli CH. Signalling pathways linking integrins with cell cycle progression. Matrix Biol (2014) 34:144-53. doi: 10.1016/ j.matbio.2013.10.011

37. Afratis NA, Nikitovic D, Multhaupt HA, Theocharis AD, Couchman JR, Karamanos NK. Syndecans - key regulators of cell signaling and biological functions. FEBS J (2017) 284(1):27-41. doi: 10.1111/febs.13940

38. Bass MD, Humphries MJ. Cytoplasmic interactions of syndecan- 4 orchestrate adhesion receptor and growth factor receptor signalling. Biochem J (2002) 368 (Pt 1):1-15. doi: 10.1042/bj20021228

39. Beauvais DM, Rapraeger AC. Syndecans in tumor cell adhesion and signaling. Reprod Biol Endocrinol (2004) 2:3. doi: 10.1186/1477-7827-2-3

40. Vlodavsky I, Ilan N, Sanderson RD. Heparanase-From basic research to clinical application. Adv Exp Med Biol (2020) 1221:3-59. doi: 10.1007/9783-030-34521-1_1

41. Daly SB, Urquhart JE, Hilton E, McKenzie EA, Kammerer RA, Lewis M, et al. Mutations in HPSE2 cause urofacial syndrome. Am J Hum Genet (2010) 86 (6):963-9. doi: 10.1016/j.ajhg.2010.05.006

42. Pang J, Zhang S, Yang P, Hawkins-Lee B, Zhong J, Zhang Y, et al. Loss-of-function mutations in HPSE2 cause the autosomal recessive urofacial syndrome. Am J Hum Genet (2010) 86(6):957-62. doi: 10.1016/j.ajhg.2010.04.016

43. Stuart HM, Roberts NA, Hilton EN, McKenzie EA, Daly SB, Hadfield KD, et al. Urinary tract effects of HPSE2 mutations. J Am Soc Nephrol (2015) 26 (4):797-804. doi: 10.1681/ASN.2013090961

44. Stahl K, Gronski PA, Kiyan Y, Seeliger B, Bertram A, Pape T, et al. Injury to the endothelial glycocalyx in critically Ill COVID-19 patients. Am J Respir Crit Care Med (2020) 202(8):1178-81 doi: 10.1164/rccm.202007-2676LE

45. Teuwen LA, Geldhof V, Pasut A, Carmeliet P. COVID-19: the vasculature unleashed. Nat Rev Immunol (2020) 20(7):389-91. doi: 10.1038/s41577-020-0343-0

46. Uchimido R, Schmidt EP, Shapiro NI. The glycocalyx: a novel diagnostic and therapeutic target in sepsis. Crit Care (2019) 23(1):16. doi: 10.1186/s13054-018-2292-6

47. Kiyan Y, Tkachuk S, Kurselis K, Shushakova N, Stahl K, Dawodu D, et al. Heparanase-2 protects from LPS-mediated endothelial injury by inhibiting TLR4 signalling. Sci Rep (2019) 9(1):13591. doi: 10.1038/s41598-019-50068-5
48. Fernandez-Vega I, Garcia O, Crespo A, Castanon S, Menendez P, Astudillo A, et al. Specific genes involved in synthesis and editing of heparan sulfate proteoglycans show altered expression patterns in breast cancer. BMC Cancer (2013) 13:24. doi: 10.1186/1471-2407-13-24

49. Fu J, Khaybullin R, Zhang Y, Xia A, Qi X. Gene expression profiling leads to discovery of correlation of matrix metalloproteinase 11 and heparanase 2 in breast cancer progression. BMC Cancer (2015) 15:473. doi: 10.1186/s12885015-1410-y

50. Doweck I, Feibish N. Opposing Effects of Heparanase and Heparanase-2 in Head \& Neck Cancer. Adv Exp Med Biol (2020) 1221:847-56. doi: 10.1007/ 978-3-030-34521-1_37

51. Zhang X, Xu S, Tan Q, Liu L. High expression of heparanase-2 is an independent prognostic parameter for favorable survival in gastric cancer patients. Cancer Epidemiol (2013) 37(6):1010-3. doi: 10.1016/ j.canep.2013.09.012

52. Casu B, Vlodavsky I, Sanderson RD. Non-anticoagulant heparins and inhibition of cancer. Pathophysiol Haemost Thromb (2008) 36(3-4):195203. doi: $10.1159 / 000175157$

53. Sotnikov I, Hershkoviz R, Grabovsky V, Ilan N, Cahalon L, Vlodavsky I, et al. Enzymatically quiescent heparanase augments $\mathrm{T}$ cell interactions with VCAM-1 and extracellular matrix components under versatile dynamic contexts. J Immunol (2004) 172(9):5185-93. doi: 10.4049/jimmunol.172.9.5185

54. Couchman JR. Syndecans: proteoglycan regulators of cell-surface microdomains? Nat Rev (2003) 4(12):926-37. doi: 10.1038/nrm1257

55. Couchman JR. Transmembrane signaling proteoglycans. Annu Rev Cell Dev Biol (2010) 26:89-114. doi: 10.1146/annurev-cellbio-100109-104126

56. Roberts NA, Woolf AS, Stuart HM, Thuret R, McKenzie EA, Newman WG, et al. Heparanase 2, mutated in urofacial syndrome, mediates peripheral neural development in Xenopus. Hum Mol Genet (2014) 23(16):4302-14. doi: $10.1093 / \mathrm{hmg} / \mathrm{ddu} 147$

57. Levy-Adam F, Abboud-Jarrous G, Guerrini M, Beccati D, Vlodavsky I, Ilan N. Identification and characterization of heparin/heparan sulfate binding domains of the endoglycosidase heparanase. J Biol Chem (2005) 280 (21):20457-66. doi: 10.1074/jbc.M414546200

58. Coombe DR, Gandhi NS. Heparanase: A challenging cancer drug target. Front Oncol (2019) 9:1316. doi: 10.3389/fonc.2019.01316

59. Wu L, Jiang J, Jin Y, Kallemeijn WW, Kuo CL, Artola M, et al. Activity-based probes for functional interrogation of retaining beta-glucuronidases. Nat Chem Biol (2017) 13(8):867-73. doi: 10.1038/nchembio.2395

60. Guo C, Kaneko S, Sun Y, Huang Y, Vlodavsky I, Li X, et al. A mouse model of urofacial syndrome with dysfunctional urination. Hum Mol Genet (2015) 24 (7):1991-9. doi: 10.1093/hmg/ddu613

Conflict of Interest: The authors declare that the research was conducted in the absence of any commercial or financial relationships that could be construed as a potential conflict of interest.

Copyright (๑) 2021 Gross-Cohen, Feld, Arvatz, Ilan and Vlodavsky. This is an openaccess article distributed under the terms of the Creative Commons Attribution License (CC BY). The use, distribution or reproduction in other forums is permitted, provided the original author(s) and the copyright owner(s) are credited and that the original publication in this journal is cited, in accordance with accepted academic practice. No use, distribution or reproduction is permitted which does not comply with these terms. 